\title{
Nesterenkonia aethiopica sp. nov., an alkaliphilic, moderate halophile isolated from an Ethiopian soda lake
}

Correspondence

Rajni Hatti-Kaul

rajni.hatti-kaul@biotek.lu.se

\author{
Osvaldo Delgado,† Jorge Quillaguamán, Shahrzad Bakhtiar, Bo Mattiasson, \\ Amare Gessesseł and Rajni Hatti-Kaul
}

\begin{abstract}
Department of Biotechnology, Centre for Chemistry and Chemical Engineering, Lund University,
\end{abstract} PO Box 124, SE-221 00 Lund, Sweden

\begin{abstract}
Strain DSM $17733^{\top}$, isolated from the shore of Lake Abjata in Ethiopia, is a heterotrophic, alkaliphilic, moderately halophilic, Gram-positive, strictly aerobic, non-motile, non-endospore-forming bacterium. The organism grows optimally at $30-37^{\circ} \mathrm{C}, \mathrm{pH} 9$ and $3 \%(\mathrm{w} / \mathrm{v}) \mathrm{NaCl}$. Analysis of the cell wall showed the presence of murein of the type L-Lys-Gly-L-Glu, variation A4 $\alpha$. The G +C content of the genomic DNA was $69.0 \mathrm{~mol} \%$. Sequence analysis of $16 \mathrm{~S}$ rRNA gene sequence of strain DSM $17733^{\top}$ placed the isolate in the genus Nesterenkonia. DNA-DNA hybridization of DSM $17733^{\top}$ with those organisms with the closest phylogenetic affiliation, i.e. Nesterenkonia halobia, Nesterenkonia lacusekhoensis and Nesterenkonia xinjiangensis, gave relatedness values of $48 \cdot 5 \%, 63 \cdot 7 \%$ (repetition, $57 \cdot 2 \%$ ) and $35.7 \%$ (repetition, $29 \cdot 3 \%$ ), respectively. On the basis of both phenotypic and phylogenetic criteria and the low levels of DNA-DNA relatedness with the phylogenetically closest species $N$. xinjiangensis and $N$. halobia, it is proposed that the isolate be classified in a novel species, Nesterenkonia aethiopica sp. nov. The type strain is DSM $17733^{\top}\left(=\operatorname{CCUG} 48939^{\top}\right)$.
\end{abstract}

The genus Nesterenkonia was proposed by Stackebrandt et al. (1995) and initially included only one species, Nesterenkonia halobia, originally classified as Micrococcus halobius (Onishi \& Kamekura, 1972). The type strain of this species was isolated from unrefined solar salt from Noda, Japan (Onishi \& Kamekura, 1972). Recently, the species Nesterenkonia lacusekhoensis, isolated from a hypersaline lake in eastern Antarctica (Collins et al., 2002), Nesterenkonia xinjiangensis and Nesterenkonia halotolerans, from hypersaline soil in China (Li et al., 2004), Nesterenkonia sandarakina, from soil in the eastern desert of Egypt, and Nesterenkonia lutea, from saline soil in China (Li et al., 2005), have been described. All Nesterenkonia species are Gram-positive, strictly aerobic and moderately halophilic or halotolerant (and some species are alkaliphilic or alkalitolerant), contain peptidoglycan of the A $4 \alpha$ type and have DNA $G+C$ contents in the range 64-72 mol\% (Li et al., 2005).

tPresent address: PROIMI-CONICET, Av. Belgrano y Pasaje Caseros, 4000 Tucumán, Argentina.

‡Present address: Department of Biology, Science Faculty, Addis Ababa University, PO Box 1176, Addis Ababa, Ethiopia.

The GenBank/EMBL/DDBJ accession number for the 16S rRNA gene sequence of strain DSM $17733^{\top}$ is AY574575.

Electron micrographs of strain DSM $17733^{\top}$ are available as supplementary material in IJSEM Online.
In this paper, we describe the characterization and classification of the alkaliphilic, moderately halophilic strain DSM $17733^{\mathrm{T}}$, which was isolated from a soiled feather sample collected on the shore of Lake Abjata in Ethiopia $\left(7^{\circ} 60^{\prime} \mathrm{N}\right.$ $\left.38^{\circ} 62^{\prime} \mathrm{E}\right)$.

Strain DSM $17733^{\mathrm{T}}$ was grown at $37^{\circ} \mathrm{C}$, with shaking at 200 r.p.m., in complex YP medium (Mota et al., 1997). Catalase and oxidase activities and sensitivity to antibiotics were tested, according to Smibert \& Krieg (1994), using YP medium, utilized previously for the taxonomic characterization of N. halobia (Mota et al., 1997). The colony characteristics of strain DSM $17733^{\mathrm{T}}$ were studied on solid Luria-Bertani (LB) medium at $\mathrm{pH} 8$ at $30^{\circ} \mathrm{C}$ (Li et al., 2005). The optimum temperature for growth was determined by using incubation at $20,30,37,40$ and $45^{\circ} \mathrm{C}$ in liquid ISP 5 medium (Tang et al., 2003). The $\mathrm{pH}$ tolerance was also investigated in ISP 5 medium at $\mathrm{pH}$ values ranging from 5 to 12 , according to the method of Li et al. $(2004,2005)$. Halotolerance was tested in ISP 5 medium with $0-20 \%(\mathrm{w} / \mathrm{v}) \mathrm{NaCl}$ at $37^{\circ} \mathrm{C}$. Hydrolysis of xylan and dextran was tested as described by Smibert \& Krieg (1994). Hydrolysis of starch and casein was tested in solid YP medium containing $1 \%(\mathrm{w} / \mathrm{v})$ soluble starch or $1.5 \%(\mathrm{w} / \mathrm{v})$ casein, respectively. Carbon-source utilization by strain DSM $17733^{\mathrm{T}}$ was determined as described previously (Li et al., 2004). Other biochemical characteristics were screened by using the API 20E system (bioMérieux), as described by Logan \& Berkeley (1984). 
Cell size and morphology were examined under a Nixon Optiphot-2 phase-contrast microscope at $\times 1000$ magnification during various different stages of cell growth in $\mathrm{YP}$ and ISP 5 media at $37^{\circ} \mathrm{C}$. Gram staining was performed using a Difco Gram-stain set. Scanning electron microscopy (JSM-5600 LV; JEOL) was performed at $\times 10000-15000$ magnification, using cells grown in YP medium at $37^{\circ} \mathrm{C}$ for 12-18 h. Cells were then harvested, washed twice with water and dehydrated with increasing concentrations of ethanol (from 40 to $80 \%, \mathrm{v} / \mathrm{v}$ ) followed by increasing concentrations of isopropanol (20-100\%, v/v), mounted on $12 \mathrm{~mm}$ cover slips, dried in a vacuum desiccator for $12 \mathrm{~h}$ and, finally, coated with gold/palladium $(80: 20)$.

Peptidoglycan was purified from the cell wall and its composition was determined at the Deutsche Sammlung von Mikroorganismen und Zellkulturen (DSMZ, Braunschweig, Germany) as described by Schleifer \& Kandler (1972) and Schleifer (1985).

Genomic DNA was extracted and purified as described by Sambrook et al. (1989). Universal primers corresponding to positions (Escherichia coli numbering) 8-27F (5'-AGAGTTTGATCCTGGCTCAG-3') and 1492-1509R (5'-GGTTACCTTGTTACGACTT-3') were used to amplify the $16 \mathrm{~S}$ rRNA gene sequence of the novel isolate by PCR (Weisburg et al., 1991). The PCR products were purified and sequenced as described previously (Quillaguamán et al., 2004).

An almost complete sequence (1449 bp) of the 16S rRNA gene of strain DSM $17733^{\mathrm{T}}$ was obtained. Sequences belonging to type strains of the genus Nesterenkonia available through the public databases (GenBank and Ribosomal Database Project II) were aligned and a similarity matrix was calculated (Maidak et al., 2000). 16S rRNA gene sequence analysis was performed with the aid of the DNAMAN 4.03 software package by using the neighbour-joining method and the Jukes-Cantor distance correction method (Saitou \& Nei, 1987); the stability of the grouping was estimated by bootstrap analyses (500 replications). Only unambiguously aligned positions from all sequences were used, and gaps were not included in the match/mismatch count.

In order to calculate $\mathrm{G}+\mathrm{C}$ content, DNA was isolated by chromatography on hydroxyapatite by the procedure of Cashion et al. (1977). The $\mathrm{G}+\mathrm{C}$ content was calculated from the ratio of deoxyguanosine to thymidine, according to the method of Mesbah et al. (1989), by the Identification Service of the DSMZ.

DNA-DNA hybridization was carried out at the DSMZ, as described by De Ley et al. (1970) with the modification described by Huß et al. (1983) and Escara \& Hutton (1980), using a Gilford System model 2600 spectrometer equipped with a Gilford model 2527-R thermoprogrammer and plotter. Renaturation rates were computed with the TRANSFER.BAS program (Jahnke, 1992).

$16 \mathrm{~S}$ rRNA gene sequence analysis placed the novel isolate in the family Micrococcaceae with a close relationship to members of Nesterenkonia (Fig. 1). The closest sequence similarities were found with N. xinjiangensis YIM $70097^{\mathrm{T}}$ (98\%; AY226510) and N. halobia DSM 20541 ${ }^{\mathrm{T}}$ (97\%; X80747).

The phenotypic features of strain DSM $17733^{\mathrm{T}}$ were investigated and compared with those of other species of the genus Nesterenkonia; differential characteristics are listed in Table 1. Strain DSM $17733^{\mathrm{T}}$ produced circular, convex, smooth, entire, opaque colonies that were white in colour but turned yellow in old cultures grown on solid LB medium. We have observed a similar change in the colour of colonies of $N$. xinjiangensis grown on LB medium. Microscopic examination of strain DSM $17733^{\mathrm{T}}$ at various stages of growth showed the cells to be non-motile, non-endosporeforming, non-capsule-forming, short rods around $0 \cdot 7 \mu \mathrm{m}$ in width and $1.2 \mu \mathrm{m}$ in length (see Supplementary Fig. S1 available in IJSEM Online). In unstained preparations, cells occur singly, in pairs and in irregular clumps (Supplementary Fig. S1).

Growth of the isolate in YP liquid medium was uniform, the broth was turbid and no pellicles were produced. The isolate was strictly aerobic and mesophilic, exhibiting good growth at $25-40{ }^{\circ} \mathrm{C}$ with an optimum between 30 and $37^{\circ} \mathrm{C}$. It was able to grow at $\mathrm{pH}$ values in the range $7-11$, with optimal growth at $\mathrm{pH}$ 9. Variation of the $\mathrm{NaCl}$ concentration in the medium showed that good growth occurred at 3-8 \% (w/v) salt, maximal growth being observed at $3 \%(\mathrm{w} / \mathrm{v}) \mathrm{NaCl}$.

Like N. halobia, the isolate exhibited sensitivity to ampicillin, chloramphenicol, nalidixic acid, streptomycin and kanamycin, but showed resistance to erythromycin and tetracycline (Stackebrandt et al., 1995). The minimal inhibitory concentrations of the antibiotics were as follows: ampicillin, $10 \mu \mathrm{g}$; tetracycline, $30 \mu \mathrm{g}$; chloramphenicol, $30 \mu \mathrm{g}$; nalidixic

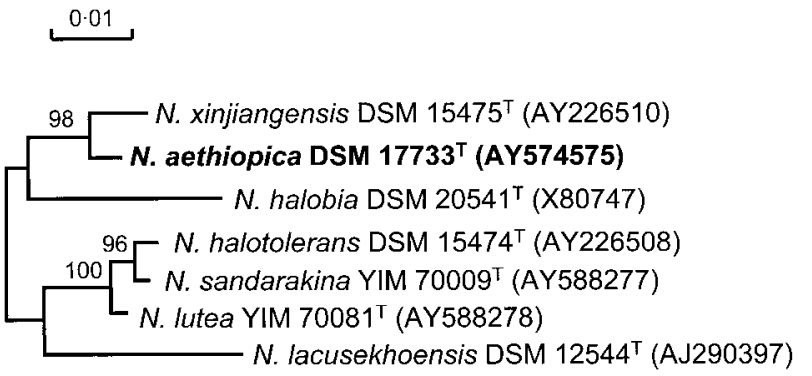

Fig. 1. Dendrogram showing phylogenetic relationships derived from $16 \mathrm{~S}$ rRNA gene sequence analysis of strain DSM $17733^{\top}$ with respect to Nesterenkonia species with validly published names. The tree was constructed using the neighbour-joining method; bootstrap values are expressed as percentages of 500 replications. The sequence of Streptomyces megasporus DSM $41476^{\top}$ (Z68100) was used as the root (not shown). Accession numbers used in the phylogenetic analysis are given in parentheses. 
Table 1. Comparison of the phenotypic characteristics of strain DSM $17733^{\top}$ and Nesterenkonia species with validly published names

Strains: 1, N. aethiopica sp. nov. DSM $17733^{\mathrm{T}} ; 2$, N. halobia DSM $20541^{\mathrm{T}} ; 3$, N. lacusekhoensis DSM 12544 ${ }^{\mathrm{T}}$; 4, N. halotolerans DSM $15474^{\mathrm{T}} ; 5$, N. xinjiangensis DSM $15475^{\mathrm{T}} ; 6$, N. sandarakina YIM $70009^{\mathrm{T}} ; 7$, N. lutea YIM $70081^{\mathrm{T}}$. All of the strains are Gram-positive, aerobic and moderately halophilic. +, Positive; -, negative; w, weak reaction; ND, not determined. Data for reference strains were taken from Collins et al. (2002), Li et al. (2004, 2005) and Stackebrandt et al. (1995).

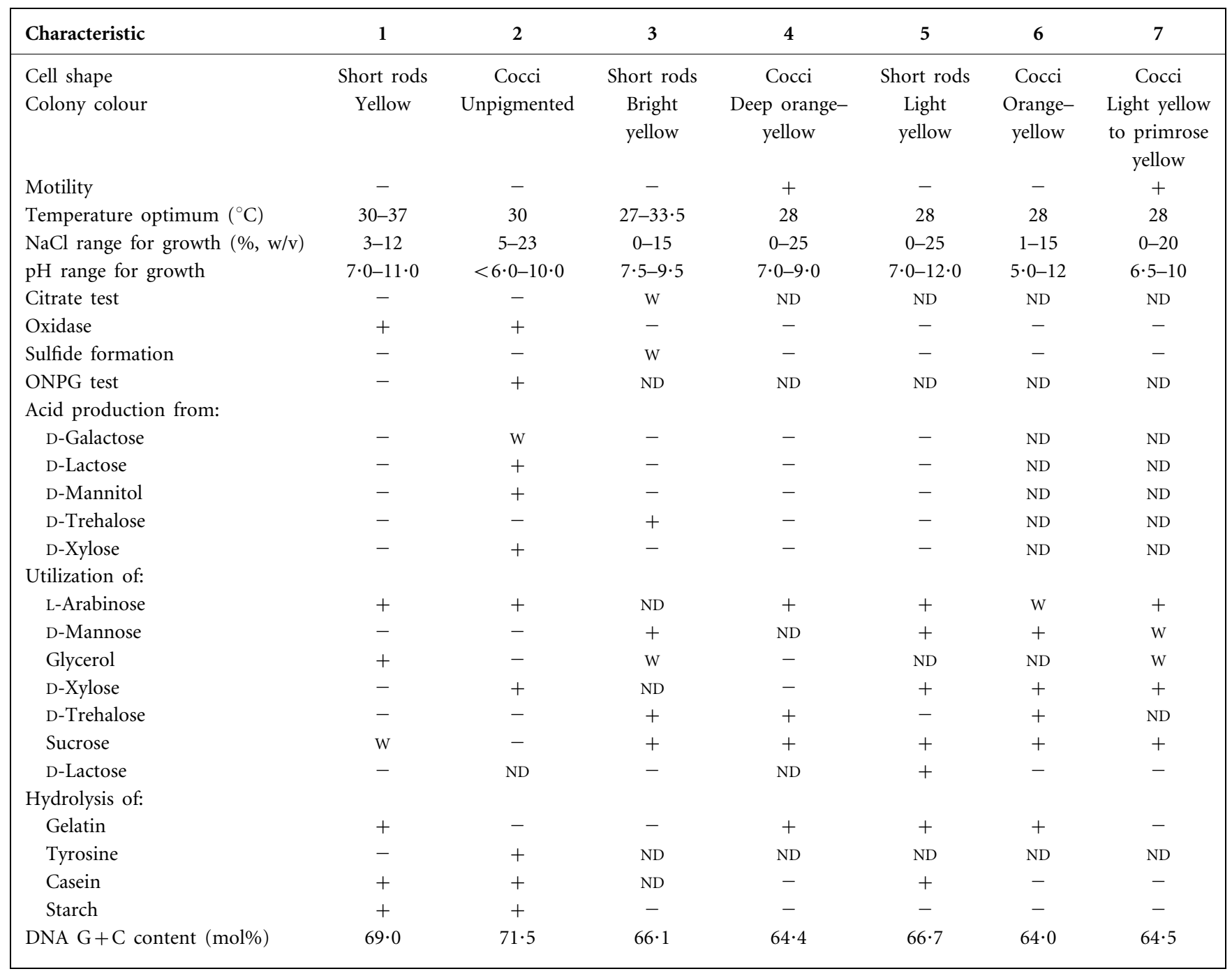

acid, $30 \mu \mathrm{g}$; kanamycin, $10 \mu \mathrm{g}$; novobiocin, $30 \mu \mathrm{g}$; streptomycin, $10 \mu \mathrm{g}$; erythromycin, $50 \mu \mathrm{g}$.

Analysis of the cell wall showed the presence of murein of the type L-Lys-Gly-L-Glu, as in N. halobia (Stackebrandt et al., 1995) and N. xinjiangensis (Li et al., 2004); this differed from the L-Lys-L-Glu reported for N. lacusekhoensis (Collins et al., 2002) and the L-Lys-Gly-D-Asp found in N. halotolerans (Li et al., 2004), N. lutea and N. sandarakina (Li et al., 2005).

As shown in Table 1, the DNA G $+C$ content of strain DSM $17733^{\mathrm{T}}$ was found to be $69.0 \mathrm{~mol} \%$, which is within the range (64-72 mol\%) reported in the emended description of the genus Nesterenkonia (Li et al., 2005). Furthermore,
DNA-DNA hybridization analysis of strain DSM $17733^{\mathrm{T}}$ revealed $48 \cdot 5 \%$ relatedness to $N$. halobia DSM $20541^{\mathrm{T}}$, $63.7 \%$ (repetition, $57 \cdot 2 \%$ ) to $N$. lacusekhoensis DSM $12544^{\mathrm{T}}$ and $35 \cdot 7 \%$ (repetition, $29 \cdot 3 \%$ ) to $N$. xinjiangensis DSM $15475^{\mathrm{T}}$. These values were below $70 \%$, the threshold value recommended for the delineation of genomic species (Wayne et al., 1987).

On the basis of notable differences in the phenotypic and phylogenetic features, the $\mathrm{G}+\mathrm{C}$ content and the relatively low levels of DNA-DNA relatedness to species belonging to the genus Nesterenkonia, we conclude that strain DSM $17733^{\mathrm{T}}$ represents a novel alkaliphilic, moderately halophilic Nesterenkonia species, for which the name of Nesterenkonia aethiopica sp. nov. is proposed. 


\section{Description of Nesterenkonia aethiopica sp. nov.}

Nesterenkonia aethiopica (L. fem. adj. aethiopica pertaining to Ethiopia).

Cells are Gram-positive, non-motile, non-capsule-forming, non-endospore-forming, short rods around $0.7 \mu \mathrm{m}$ in width and $1.2 \mu \mathrm{m}$ in length. Catalase- and oxidase-positive and urease-negative. Strictly aerobic and mesophilic: exhibits good growth at $25-40{ }^{\circ} \mathrm{C}$, with an optimum between 30 and $37^{\circ} \mathrm{C}$; unable to grow at $45^{\circ} \mathrm{C}$. Alkaliphilic and moderately halophilic. Optimal growth occurs at initial $\mathrm{pH} 9$ (range $\mathrm{pH} 7-11)$ and at 3\%(w/v) $\mathrm{NaCl}$ (range 3-12\%). Carbohydrates utilized as sole carbon sources are D-glucose, D-fructose and other sugars listed in Table 1. Acid is produced in medium supplied with D-glucose, D-fructose, Larabinose and glycerol, but acidification is not detected with D-trehalose, D-galactose, D-lactose, D-mannitol or D-xylose. Starch, casein, tyrosine and gelatin are hydrolysed. Indole is not produced and the Voges-Proskauer test is negative. The DNA $\mathrm{G}+\mathrm{C}$ content is $69 \cdot 0 \mathrm{~mol} \%$ (determined by HPLC). Cell wall has murein of the type L-Lys-Gly-L-Glu.

The type strain, DSM $17733^{\mathrm{T}}\left(=\mathrm{CCUG} 48939^{\mathrm{T}}\right)$, was isolated from a soiled feather sample collected at the shore of Lake Abjata, Ethiopia.

\section{Acknowledgements}

This work was supported by the Swedish International Development Cooperation Agency (Sida; SWE-2000-385).

\section{References}

Cashion, P., Holder-Franklin, M. A., McCully, J. \& Franklin, M. (1977). A rapid method for the base ratio determination of bacterial DNA. Anal Biochem 81, 461-466.

Collins, M. D., Lawson, P. A., Labrenz, M., Tindall, B. J., Weiss, N. \& Hirsch, P. (2002). Nesterenkonia lacusekhoensis sp. nov., isolated from hypersaline Ekho Lake, East Antarctica, and emended description of the genus Nesterenkonia. Int J Syst Evol Microbiol 52, $1145-1150$

De Ley, J., Cattoir, H. \& Reynaerts, A. (1970). The quantitative measurement of DNA hybridization from renaturation rates. Eur $J$ Biochem 12, 133-142.

Escara, J. F. \& Hutton, J. R. (1980). Thermal stability and renaturation of DNA in dimethyl sulfoxide solutions: acceleration of the renaturation rate. Biopolymers 19, 1315-1327.

Huß, V. A. R., Festl, H. \& Schleifer, K. H. (1983). Studies on the spectrometric determination of DNA hybridization from renaturation rates. Syst Appl Microbiol 4, 184-192.

Jahnke, K. D. (1992). Basic computer program for evaluation of spectroscopic DNA renaturation data from GILFORD System 2600 spectrometer on a PC/XT/AT type personal computer. J Microbiol Methods 15, 61-73.

Li, W. J., Chen, H. H., Zhang, Y. Q., Schumann, P., Stackebrandt, E., Xu, L. H. \& Jiang, C. L. (2004). Nesterenkonia halotolerans sp. nov. and Nesterenkonia xinjiangensis sp. nov., two novel actinobacteria from saline soils in the west of China. Int J Syst Evol Microbiol 54, 837-841.

Li, W. J., Chen, H. H., Kim, C. J., Zhang, Y. Q., Park, D. J., Lee, J. C., Xu, L. H. \& Jiang, C. L. (2005). Nesterenkonia sandarakina sp. nov. and Nesterenkonia lutea sp. nov., novel actinobacteria, and emended description of the genus Nesterenkonia. Int J Syst Evol Microbiol 55, 463-466.

Logan, N. A. \& Berkeley, R. C. W. (1984). Identification of Bacillus strains using the API system. J Gen Microbiol 130, 1871-1882.

Maidak, B. L., Cole, J., Lilburn, T. \& 9 other authors (2000). The RDP (Ribosomal Database Project) continues. Nucleic Acids Res 28, 173-174.

Mesbah, M., Premachandran, U. \& Whitman, W. B. (1989). Precise measurement of the $\mathrm{G}+\mathrm{C}$ content of deoxyribonucleic acid by high-performance liquid chromatography. Int J Syst Bacteriol 39, 159-167.

Mota, R. R., Marquez, C., Arahal, D., Mellado, E. \& Ventosa, A. (1997). Polyphasic taxonomy of Nesterenkonia halobia. Int J Syst Bacteriol 47, 1231-1235.

Onishi, H. \& Kamekura, M. (1972). Micrococcus halobius sp. nov. Int $J$ Syst Bacteriol 22, 233-236.

Quillaguamán, J., Hatti-Kaul, R., Mattiasson, B., Alvarez, M. T. \& Delgado, O. (2004). Halomonas boliviensis sp. nov., an alkalitolerant, moderate halophile isolated from soil around a Bolivian hypersaline lake. Int J Syst Evol Microbiol 54, 721-725.

Saitou, N. \& Nei, M. (1987). The neighbor-joining method: a new method for reconstructing phylogenetic trees. Mol Biol Evol 4, 406-425.

Sambrook, J., Fritsch, E. F. \& Maniatis, T. (1989). Gel electrophoresis of DNA. In Molecular Cloning: a Laboratory Manual, 2nd edn, pp. 6.3-6.19. Edited by C. Nolan. Cold Spring Harbor, NY: Cold Spring Harbor Laboratory.

Schleifer, K. H. (1985). Analysis of the chemical composition and primary structure of murein. Methods Microbiol 18, 123-156.

Schleifer, K. H. \& Kandler, O. (1972). Peptidoglycan types of bacterial cell walls and their taxonomic implications. Bacteriol Rev 36, 407-477.

Smibert, R. M. \& Krieg, N. R. (1994). Phenotypic characterization. In Methods for General and Molecular Bacteriology, pp. 611-651. Edited by P. Gerhardt, R. G. E. Murray, W. A. Wood \& N. R. Krieg. Washington, DC: American Society for Microbiology.

Stackebrandt, E., Koch, C., Gvozdiak, O. \& Schumann, P. (1995). Taxonomic dissection of the genus Micrococcus: Kocuria gen. nov., Nesterenkonia gen. nov., Kytococcus gen. nov., Dermacoccus gen. nov., and Micrococcus Cohn 1872 gen. emend. Int J Syst Bacteriol 45, 682-692.

Tang, S. K., Li, W., Wang, D., Zhang, Y. G., Xu, L. H. \& Jiang, C. L. (2003). Studies of the biological characteristics of some halophilic and halotolerant actinomycetes isolated from saline and alkaline soils. Actinomycetologica 17, 6-10.

Wayne, L. G., Brenner, D. J., Colwell, R. R. \& 9 other authors (1987). International Committee on Systematic Bacteriology. Report of the ad hoc committee on reconciliation of approaches to bacterial systematics. Int J Syst Bacteriol 37, 463-464.

Weisburg, W. G., Barns, S. M., Pelletier, D. A. \& Lane, D. J. (1991). 16 S ribosomal DNA amplification for phylogenetic study. J Bacteriol 173, 697-703. 